\title{
Effect of School Feeding Programme on Pastoralists' Pupils' Participation in Regular and Mobile Primary Schools in Turkana County, Kenya
}

\author{
Paul Ekeno Ejore (Corresponding author) \\ Lecturer, Department of Educational Foundations \\ Koitalel Samoei University College, Kenya \\ E-mail: paulejore@gmail.com \\ Daniel Komo Gakunga \\ Senior Lecturer \\ Department of Educational Foundations \\ University of Nairobi \\ Musembi Nungu \\ Lecturer \\ Department of Educational Foundations \\ University of Nairobi
}

Received: Sep. 12, 2020

Accepted: Oct. 19, $2020 \quad$ Published: November 1, 2020

doi:10.5296/jse.v10i4.17747

URL: https://doi.org/10.5296/jse.v10i4.17747

\begin{abstract}
Kenya's Turkana County, being an arid area, is faced with numerous challenges that hinder education programs especially among school going pupils. Therefore, the study sought to establish the effectiveness of the government interventions measures on pastoralists' pupils' participation in regular and mobile primary schools in Turkana County. Based on the study, this paper explores the effectiveness of the school feeding programme in promoting access to
\end{abstract}




\section{Macrothink}

education among pupils from pastoralist communities in the County. The study utilized both descriptive survey as well as mixed methods. It utilised a sample of 75 head teachers, 225 teachers, 375 pupils, 85 parents, 3 education officers (1 from each sub-county), 1 County Director of Education and 1 County Commissioner. For data collection, the study employed questionnaires, interview schedules and focus group discussions. Quantitative data was coded and keyed into the computer using Statistical Package for Social Science (SPSS). In order to test the effectiveness of the government intervention, regression test an (inferential statistics) was applied. The analysed data was presented using tables. The qualitative data from interview schedules and focused group discussion was organized into major themes as per the research objectives. The results were presented thematically using extensive description and direct quotations. Hypotheses were analysed using regression analysis. The findings of the study showed that the feeding programme influenced many pastoralists' pupils' participation in both regular and mobile primary schools. The study recommends that the government should make efforts to ensure that food is supplied to schools in in time. There is also need to enrich the nutritional quality of the food supplied to schools. This paper highlights the major contribution of school feeding interventions in increasing access to quality education among marginalised communities. It will inform future policies aimed at such interventions by governments and education stakeholders.

Keywords: effectiveness, school feeding programme, pastoralist pupils, participation, regular, mobile primary schools, Turkana, Kenya 


\section{Introduction}

Issues relating to education access and participation among pastoralist communities have increasingly gained international attention because education is considered a basic human right. Through education, it is believed that poverty can be fought and individuals are better guaranteed the opportunity to improve their well-being. As such, so serious is the issue of education access that the UK government demands that education providers make accessibility to all areas paramount (Migosi, Nanok, Ombuki \& Metet, 2012). Despite the emphasis on the need to increase education access and participation, over 125 million children are not in school across the world (Tilak, 2005). Majority of the children out of school are in Asia and sub-Saharan Africa. Whereas the factors that keep the children out of school are quite challenging, efforts have been made around the world to guarantee every child access and participation in education.

While indications of unemployment for the educated are on the rise in many countries in Africa, schooling is still the only option for upward mobility for the poor (Nkinyangi, 1981). Populations in these countries are thus compelled to clamour for education and their governments have responded by allocation of resources to education (Nkinyangi, 1981). Education benefits extend beyond an individual, to the family and even to the nation. Therefore, ensuring access to quality education completion results in economic growth, improved social services and a reduction in crime (Migosi et al., 2012).

Children from pastoralist populations are obstructed from accessing education by a number of factors, including sparse distribution of the populations (Adan, 2010; Porta \& Wils, 2013; Sifuna, 2005). Because of the sparse distribution of pastoralist populations, gathering enough pupils for cost effectiveness is difficult (Porta \& Wils, 2013). Government interventions in such populations are believed to have the ability to address the school access issue. Another barrier to education access stems from the fact that children from these communities are also seen as assets because of their role in contributing economically to their families through their labour from a tender age (Carr-Hill, Eshete, Sedel \& de Souza, 2005). Therefore, pastoralist parents tend to be reluctant to send their children to school (Porta \& Wils, 2013).

Pastoralist communities thus do not see school for what other communities see; they consider school and schooling as an alien thing that does not contribute to their pastoral way of life (Kratli, 2001). Most pastoral communities do not want to change their traditional ways of life (Abdirahman, 2016). To them school will alienate and eventually separate their children from them and the society at large (Kratli, 2001). Evidence from Nigeria demonstrate that curriculum inappropriateness is a hindrance to schooling among nomadic populations (Aderinoye, Ojokheta \& Olojede, 2007).

\subsection{Effectiveness of the School Feeding Programme}

Taylor (2009) asserts that pastoralist communities experience drought frequently. He further asserted that children who are stunted, anaemic experience hunger or have poor dietary intakes tend to have poorer school performance including late enrolment and poor attendance, behaviour, cognation and achievement levels. Thus they are more likely to drop out of school 
early and repeat grades. Availing the requisite nutritional and related interventions at schooling period will enhance the pupils' achievement. Enhancing health and diet levels among pupils leads to high participation through regular attendance, reduced drop-out and bolstered academic outcomes and to social equity and economic growth as healthy persons have the energy to work. Taylor simply provides recommendations on the benefits of school feeding programmes. However, he does not offer any assessment on the effectiveness of school feeding programmes in ASAL regions. Therefore, this study sought to establish whether school feeding programme introduced in pastoralist communities have impact on pupil's participation in schools.

Wolpert and Wheeler (2008) in their study conducted in England established that educational output was enhanced among a cohort of learners provided with Omega-3 fatty acids. These students showed higher scores on tests measuring verbal intelligence, learning skills, and memory after six months and one year as compared to a control group of students who did not receive the drink. Wolpert and Wheeler's study was conducted in England, a region that bears no close resemblance socio-economically to Turkana County, which is an ASAL region. Therefore, the findings from Wolpert and Wheeler's research are only useful for conceptual or theoretical reasons in this study. However, they may not be generalized to Turkana County. As such, the present research sought to document the types of school feeding programmes offered to pupils in regular and mobile primary schools in Turkana and to measure the effectiveness of those intervention measures in enhancing pupils' participation in school.

According to Feeding Rwanda (2012), the Government of Rwanda and UNCEF highlighted school feeding as an effective approach to deal with chronic malnutrition among children in the country. In addition to improving nutrition, school meals can result in positive educational outcomes, such as better attendance and capacity to learn at school. The World Food Programme (WFP) argues that school feeding programmes are an incentive for poor children, particularly girls to go to and stay in school and improve their capacity to learn. The government in collaboration with WFP is already providing school feeding in areas it has identified as food insecure. WFP has planned to phase out its support of the school feeding programme and transfer full responsibility for it to the government by 2012. This plan was revised in 2011 and WFP now intends to increase the number of children provided with school meals by 30 percent while it prepares the government and communities to take ownership of the programme. The Feeding Rwanda study was conducted in Rwanda while the current study was carried out in Kenya to assess effectiveness of school feeding program on pastoralists' pupils' participation in regular and mobile primary learning institutions in the County of Turkana.

According to Kariuki, Chepkoech, Muthoni and Kosgei (2013), Makueni District has been availing school daytime meals to every learning institution with significant help support from the World Food Programme (WFP), parents assist to produce some foodstuffs. The aim was to ensure that children are not hungry. Performance is attributed to a well-sustained school meals programme. Considering that Makueni is an ASAL area, it was of interest to the researcher also to establish whether such programmes were effective in Turkana County 
where the government provide food as a mechanism of increasing enrolment among the pastoralist communities.

Jensen (2010) avers that school feeding mostly takes place within the context of broad national school reform programs. These reforms should focus on other essential inputs to education and learning such as teacher development, curriculum reforms and student assessment. National ministries or organizational dealing with education should not be encouraged to take on school feeding at the expense of other educational inputs as it is difficult politically to refuse food aid. Pediatre (2001) also adds that attendance and school performance are greatly enhanced by school feeding program. Many schools are already struggling to manage barely functional education systems and to assume the additional burden of food distribution. In light of these views, it was interesting to ascertain how the Kenya government balances its options between providing school feeding interventions and other educational resources in the County of Turkana. Therefore, the present study sought to assess the effectiveness of school feeding program on pastoralists' pupils' participation in regular and mobile primary schools in Turkana County. Adelman, Gilligan and Lehrer (2008) show that the provision of food offsets the cost of educating children by making available additional income for households, and consequently raising the benefits of being in school. This is called an income output of school feeding. When this income effect is large, it can cause households to send their children to school at a relatively younger age thereby minimizing the possibility of late entry.

Secondly, the 'neighbourhood effect' resulting from School Feeding Program may also influence the age at entry. That means the act of households to send their children to school earlier with the commencement of School Feeding Programme would create a social pressure and prompt similar action on the part of those who have not enrolled their children yet (Adelman et al., 2008). Therefore, the present study sought to assess the effectiveness of school feeding program on pastoralists' pupils' participation in regular and mobile primary schools in the County of Turkana.

The desire of all countries to tackle ably the difficulties emanating from the spreading globalization led to the mooting of MDGs in 2000. In these MDGs focus was given to doing away with hunger and poverty as stipulated in goal 1 . The sub goal formulated hereby is by the year 2015, the proportion of people who suffer from hunger is halved as compared to 1990 (UNO, 2005a). The UN Hunger Task Force (2004) preferred seven action points to realise this aim. Among the measures was the adoption of school meals strategies with locally sourced foodstuff. The Taskforce regards school meals programs as a good mixture of education and farming. To the Taskforce, SFPs should enhance pupils' attendance, particularly among females and, subsequently, inspire the consumption of locally sourced foodstuff.

The above-mentioned Taskforce further proposes wide-ranging community- and school-oriented feeding plans that incorporates regular de-worming, diet improvement, take-home servings, secure cooking apparatus, healthy drinking water, and enhanced overall hygiene. In addition, education on HIV/AIDS, health, nutrition, and hygiene should be 
included. All these ingredients taken together provide a good platform for improving schools, keeping children healthy and engaging the community (UNO, 2005b). The UNO study identifies the benefits of school feeding programmes, but it does not say anything about the evaluation of effectiveness of school feeding programmes. Therefore, the present study sought to assess the effectiveness of school feeding program on pastoralists' pupils' participation in regular and mobile primary schools in Turkana County.

The New Partnership on Africa's Development adopted the approach of the UNHTF and focuses on the combination of school feeding program and agriculture. The NEPAD Secretariat has come up with the Comprehensive Africa Agriculture Development Programme (CAADP), which serves as a platform for the rejuvenation of agriculture, development, sustainable food supply, and upcountry expansion in Africa. In this purview, the third pillar examines particularly the need to increase food availability and diminish hunger. It entails these aims: (1) to diminish poor nutrition in schooling learners through diet improvement through a complete and sufficient serving, and (2) to widen local push for food products and to stimulate production by smallholder farms (NEPAD, 2005a). NEPAD offers the strategies to enhance school feeding programmes in school. However, it does not mention the need to evaluate the effectiveness of these school feeding programmes. Therefore, the present study sought to assess the effectiveness of school feeding program on pastoralists' pupils' participation in regular and mobile primary schools in the County of Turkana.

New Partnership for African Development has formulated an indicator of improvement: the provision of basic school lunches that are balanced in terms of calorie and micronutrient content to 1.000 .000 children in poor and vulnerable areas throughout the NEPAD member states (NEPAD, 2005b). Global statistics reveal that, in the duration of 2000 to 2002, more than 851 million people, children being the majority, globally were insufficiently nourished. Most of these were in developing countries, but even in the United States, more than 3 million children experienced 'food insecurity with hunger' in the period between 1998 and 2000 (WFP, 2006a). Early malnutrition and/or micronutrient deficiencies can adversely affect physical, mental, and social aspects of child health. Effects on physical health may include underweight, stunted growth, lowered immunity, and mortality.

According to Hutchinson, Vickers, Jackson and Wilkes (2006) in developing countries, school feeding also aims to increase school attendance, enrolment and to encourage students to stay in school longer. School feeding programmes positively affect educational attainment by increasing enrolment and attendance, reducing absenteeism due to illness and decreasing dropout. In most states, school feeding programs are one of the key incentives to encourage children, more so females and the most poor and high-risk, to attend school. In December 2009, WFP reported that a boy who graduated from a primary school in Cameroon where the WFP provided free daily lunches to students stated, "At home we usually eat millet. But at my primary school we got to eat rice and beans, so all the children in my area wanted to go!" School feeding program may also serve as incentives for poor households to allow their kids to go learn. Attendance rates are lowest for children from poor households and providing school meals to children in qualifying families can be the equivalent of adding an extra $10 \%$ to average household incomes. In this way, school feeding program serve as social safety nets 
for poor households (WFP, 2006b). The present study sought to ascertain whether or not school feeding programmes in regular and mobile schools had served as social safety nets for the poor households in the County of Turkana. To this end, the study sought to assess the effectiveness of school feeding program on pastoralists' pupils' participation in regular and mobile primary schools in the County of Turkana.

A vital issue in school feeding research is that, in poor homes, the diet may be scaled down for kids who that get food in school: this is understood as 'substitution'. For instance, an overview on school meals plan in Malawi revealed that $77 \%$ of kids stated that they received less rations at home when they got school food. Caregivers substantiate this; $82 \%$ of caregivers reported that substitution was occurring. When there is extra food, it is used to benefit other household members, particularly children (Mutangadura, Mukurazita \& Jackson, 2003). The present study sought to determine if the food provided to schools by the government were sufficient and of the recommended quality. Therefore, the present study sought to assess the effectiveness of school feeding program on pastoralists' pupils' participation in regular and mobile primary schools in Turkana County.

The primary assumption of SFPs is that education and learning depend on good nutrition. However, in designing and implementing a school feeding program, a number of options are available, depending on the primary and secondary objectives of the program. SFPs can include simple snack servings (often enriched biscuits) to early morning meals or lunches, as well as take-home servings. Often, these programs operate in conjunction with other health and nutrition initiatives to increase their success and impact. A number of categories of SFPs exist, linked to the primary objectives of the program; increase enrolment and attendance and/or decrease gender disparity, alleviate short-term hunger and thereby increasing learning capacity.

According to Greenhalgh, Kristjansson and Robinson (2007), well-established SPFs can be aimed reasonably precisely, albeit hardly so effectively, as the most forward-looking of cash movement. In extremely poor states, where education participation is diminished, SFP may not get to the neediest groups, yet in such areas substitute safety net alternatives are usually very limited. Subsequently, geographically aimed expansion of SFP can still offer the best choice for robust scale-up of safety nets. Overall, there is proof that SFPs enhance school participation, mental acuity, and academic achievement, especially if fortified by supplementary measures such as deworming and micronutrient fortification or supplementation. Policy evaluation also reveals that the efficacy and lasting nature of SFPs is reliant on rooting the programs into education policy. Hence, the worth of SFP is determined by the degree to which there is educational accruing from them. Greenhalgh et al. provides useful literature on how to implement school feedings programmes in schools. However, they do not identify ways for analysing whether these programmes are achieving their desired ends. In light of these postulations, this study assessed the effectiveness of school feeding program on pastoralists' pupils' participation in regular and mobile primary schools in the County of Turkana. 
According to the World Bank (2013) social protection program may broaden education opportunities for children from poor households. School feeding programs, where children who attend school regularly are provided with a meal at school every day, are attractive social protection options as they are able to address dual development issues simultaneously. These programs have shown substantial benefits for both the education and social protection of children from impoverished families (Bundy, Burbano, Grosh, Gelli, Jukes \& Drake, 2009). In order for primary level education to be beneficial, children must enter primary school at an appropriate age, progress through the system and complete a full cycle. Research shows that six years of primary education are required to attain the levels of literacy and numeracy necessary for education to be able to improve lives.

Many children who do enter primary school, however, drop out early without completing the full cycle. In 22 poor countries, 30 percent or more of young adults have completed fewer than four years of education. In eleven Sub-Saharan African countries, this figure rises to 50 percent or above. In 26 countries, 20 percent of school leavers have fewer than two years' education while in countries like Burkina Faso and Somalia, the number is above 50 percent (Mutangadura et al., 2003). The study by Mutangadura et al. informs the present study in that it provides information relevant to education in ASALs. However, the present study was conducted in Turkana County of Kenya to evaluate the effectiveness of school feeding program on pastoralists' pupils' participation in regular and mobile primary schools in the County of Turkana. School feeding programs positively affect educational attainment by increasing enrolment and attendance, reducing absenteeism due to illness and decreasing dropout.

In most states, school feeding programs are one of the key incentives to encourage children to attend school (Powell \& Fazio, 2006). WFP reported that a boy who graduated from a primary school in Cameroon where the WFP provided free daily lunches to students stated, "At home we usually eat millet. But at my primary school we got to eat rice and beans, so all the children in my area wanted to go" (WFP, 2012). SFPs may also serve as incentives for poor households to let their kids to go for learning. Attendance rates are lowest for children from poor households and providing school meals to children in qualifying families can be the equivalent of adding an extra 10 percent to average household incomes (Bundy et al., 2009). In this way, school feeding programs serve as social safety nets for poor households of pastoral and agro-pastoral areas.

Studies such as WFP (2012) and Bundy et al. (2009) concur that school feeding programmes do lead to increased enrolments in education in developing countries. Considering that developing countries are always dealing with emerging challenges, it is important to constantly test such postulations in an empirical study. Hence, the present study examined the effectiveness of school feeding program on pastoralists' pupils' participation in regular and mobile primary schools in Turkana County.

Education systems are undermined when children who do attend school are unable to get the full benefit of doing so due to being malnourished. School feeding programs are not only useful in encouraging children to enrol and stay in school but also for enhancing their 
learning. Malnourished children lack the capacity for learning possessed by their well-nourished peers. Overall malnutrition undermines cognitive development, resulting in irreversible losses for learning opportunities for the future (WFP, 2007). The lowering of human acumen due to avoidable factors is a travesty, even illegal and waste. Well-designed food programs that include micronutrient fortification can provide vast nutritional benefits, thus mitigating the undermining effect that malnutrition has on children's education (UNICEF, 2007).

Studies such as UNICEF (2007), WFP (2012) and Bundy et al. (2009) concur that school feeding programmes do lead to increased enrolments in education in developing countries. Considering that developing countries are always dealing with emerging challenges, it is important to constantly test such postulations in an empirical study. Hence, the present study examined the effectiveness of school feeding program on pastoralists' pupils' participation in regular and mobile primary schools in the County of Turkana.

\subsection{Statement of the Problem}

The Kenya government and other development partners have made numerous interventions and efforts to avail formal education to the nomadic pastoralists as a means of mainstreaming and facilitating their social, political, and economic inclusion. The government of Kenya introduced Free Primary Education, school feeding programme and provision of government security in primary schools in order to increase enrolments and participation of pastoralists' pupils in regular and mobile primary schools. Despite these interventions, the effectiveness of such programmes in relation to pastoralists' pupils' participation in regular and mobile primary schools is yet to be established. This is in view of the huge amount of resources that the government uses and the need to check the desired output of these interventions.

However, it is also important to note that most of the studies done on pastoralists' pupils' participation in primary education may not have focused on pastoralists' pupils' participation in regular and mobile primary schools. Hence the research gap identified by this study. This study therefore sought to establish the effectiveness of school feeding programme, one of the government's intervention measures, on pastoralist pupil's participation in regular and mobile primary education in the County of Turkana, Kenya.

\section{Method}

The study was conducted in Turkana County, in Northern Kenya. It utilized descriptive survey research design. The target population for the study were 45250 pupils, 907 teachers, 219 head teachers, 9050 parents from 219 schools, 3 Sub-County Directors of Education (each representing the three sub-counties of Turkana Central, Loima and Turkana West) and 1 County Director of Education. To identify respondents, the study utilized simple random sampling and purposive sampling. Simple random sampling was used to sample schools, pupils, teachers, head teachers and parents of the public primary schools in every sub-county while purposive sampling was used to select the Sub-County Directors of Education, County Director of Education and County Commissioner. 


\section{Mll Macrothink}

Journal of Studies in Education

ISSN 2162-6952

2020, Vol. 10, No. 4

Five standard seven pupils, three teachers, one head teacher and one parent were sampled in every primary school in each sub-county. In Turkana West Sub-county, the researcher had a sample size of 5 mobile and 20 regular primary schools, 5 and 20 head teachers from the mobile and regular primary schools, respectively, 15 teachers from mobile schools and 60 teachers from regular schools, 5 parents from mobile and 20 from regular schools, and 25 pupils from mobile and 100 pupils from regular public primary schools, as well as 1 Assistant County Director of Education. In Loima Sub-County, the researcher had a sample size of 5 mobile and 15 regular public primary schools, 5 head teachers from mobile and 15 head teachers from regular schools, 15 teachers from mobile and 45 teachers from regular schools, 5 parents from mobile and 15 from parents regular schools, 25 pupils from mobile and 75 pupils from regular schools, and 1 Assistant County Director of Education. In Turkana Central Sub-County, the researcher sampled 30 public primary schools, comprising 18 regular schools and 12 mobile schools. Out of these schools, 12 head teachers were picked from mobile schools and 18 were picked from regular schools. Moreover, 36 teachers from mobile schools and 54 teachers from regular schools were selected. Additionally, 12 parents from mobile and 18 from regular schools were selected. Regarding pupils, 60 were selected from mobile schools and 90 were drawn from regular schools. Lastly, 1 Assistant County Director of Education was selected from the Sub-County.

This study employed questionnaires to collect data from the pupils, teachers and head teachers. Interview schedules were used to collect data from the Sub-County Education Officers, the Director of Education and the County Commissioner. Lastly, focus group discussions was used to collect data from the parents. Quantitative data was coded and keyed in to the computer using Statistical Package for Social Science (SPSS). Descriptive statistics used included frequencies, mean, percentage and standard deviation. In order to test the effectiveness of the government intervention, regression test an (inferential statistics) was used. The analysed data was presented using tables. The qualitative data form interview schedules and focused group discussions was organized into major themes as per the research objectives. The results were presented thematically using extensive description and direct quotations. Hypotheses were analysed using regression analysis. Regression analysis was used to determine the relative contribution of the government interventions to the pastoralist's pupils' participation in regular and mobile primary schools.

\section{Results and Discussion}

The study sought to establish the influence of school feeding programme on pastoralists' pupils' participation in public primary schools in Turkana County. To this effect, the respondents were asked to give their views on statements relating to school feeding programme and pupils' participation in primary education in Turkana County.

\subsection{Pupils' Views on Provision of Nutritional Meals}

Table 1 below shows pupils' overall views on school feeding programme. 
Table 1. Pupils' views on school feeding programme

\begin{tabular}{|c|c|c|c|c|c|c|}
\hline \multirow[t]{3}{*}{ Distance to school } & \multicolumn{2}{|c|}{ Regular Schools } & \multicolumn{2}{|c|}{ Mobile Schools } & \multicolumn{2}{|c|}{ Total } \\
\hline & Yes & No & Yes & No & $\mathrm{F}$ & $\%$ \\
\hline & $\mathrm{F}(\%)$ & $\mathrm{F}(\%)$ & $\mathrm{F}(\%)$ & $\mathrm{F}(\%)$ & & \\
\hline $\begin{array}{l}\text { Free meals are offered in this } \\
\text { school }\end{array}$ & $253(100)$ & $0(0)$ & $120(100)$ & $0(0)$ & 373 & 100 \\
\hline $\begin{array}{l}\text { Sometimes this school receives } \\
\text { food long after it has opened }\end{array}$ & $253(100)$ & $0(0)$ & $120(100)$ & $0(0)$ & 373 & 100 \\
\hline $\begin{array}{l}\text { Food received in this school } \\
\text { does not sustain the school to the } \\
\text { very end of term }\end{array}$ & $253(100)$ & $0(0)$ & $120(100)$ & $0(0)$ & 373 & 100 \\
\hline $\begin{array}{l}\text { The meals offered in this school } \\
\text { are nutritious and dietary }\end{array}$ & $253(100)$ & $0(0)$ & $120(100)$ & $0(0)$ & 373 & 100 \\
\hline $\begin{array}{l}\text { When there is no food in school } \\
\text { some pupils don't go to school }\end{array}$ & 251(99) & $2(1)$ & $120(100)$ & $0(0)$ & 373 & 100 \\
\hline $\begin{array}{l}\text { This school normally send } \\
\text { pupils to collect water and } \\
\text { firewood }\end{array}$ & $249(98)$ & $4(2)$ & $114(95)$ & $6(5)$ & 373 & 100 \\
\hline $\begin{array}{l}\text { When food is in school some } \\
\text { pupils remain in school even } \\
\text { after the school has closed }\end{array}$ & $226(89)$ & $27(11)$ & $101(84)$ & $19(14)$ & 373 & 100 \\
\hline
\end{tabular}

Data contained in Table 1 showed that pupils in mobile and regular schools agreed that free meals are offered in their schools. This was attested by all 100 percent response of the pupils implying that school feeding programme is 100 percent implemented in schools. The pupils also stated that sometimes their school received food long after it had opened implying that although, the food is offered it is disbursed long after it should be disbursed. This statement concurs with the statement that the food received in the school does not sustain the school to the very end of term. This was also attested to by 100 percent response of pupils from both regular and mobile schools.

The results indicated that even though there was food supply, it was of less nutritional value. This was attested by 100 percent response of the pupils who negated with the meals offered in this school are nutritious and dietary. The results implied that the nourishment availed is not nutritive enough. On statements relating to whether the school feeding programme influenced retention rates in school, 99 percent of pupils from regular schools and 100\% from mobile schools strongly agreed with the statement that when there is no food in school some pupils do not attend to school. This implies that a school-feeding programme is an incentive for pupils to attend school.

\subsection{Teachers' Views on Effect of School Feeding on Participation}

The teachers in regular schools were asked to give their opinions regarding the effect of school feeding on participation in schooling. Their feedback was as tabulated in Table 2. 
Table 2. Teachers' views on the feeding programme in schools

\begin{tabular}{|c|c|c|c|c|c|}
\hline \multicolumn{6}{|c|}{ RS-Regular Schools (n=111), MS-Mobile Schools $(n=96)$} \\
\hline & $\begin{array}{c}\text { School } \\
\mathrm{S}\end{array}$ & SD & $\mathrm{D}$ & $\mathrm{A}$ & SA \\
\hline \multirow{2}{*}{$\begin{array}{l}\text { The school provide meals to all pupils on a daily } \\
\text { basis }\end{array}$} & RS & 0.3 & 0.2 & 35.1 & 60.4 \\
\hline & MS & - & - & 24.0 & 76.0 \\
\hline \multirow[t]{2}{*}{ The meals provided are dietary and nutritious } & $\mathrm{RS}$ & 89.2 & 10.8 & - & - \\
\hline & MS & 80.2 & 19.8 & - & - \\
\hline \multirow{2}{*}{$\begin{array}{l}\text { We witness reduced cases of attendance when meals } \\
\text { are not offered }\end{array}$} & $\mathrm{RS}$ & - & - & 10.8 & 89.2 \\
\hline & MS & - & - & 11.5 & 88.5 \\
\hline \multirow{2}{*}{$\begin{array}{l}\text { The school solely rely on the government and } \\
\text { well-wishers for food donations }\end{array}$} & $\mathrm{RS}$ & - & - & 5.4 & 94.6 \\
\hline & MS & - & - & 7.3 & 92.7 \\
\hline \multirow{2}{*}{$\begin{array}{l}\text { Sometimes we send pupils to collect firewood and } \\
\text { water }\end{array}$} & $\mathrm{RS}$ & 3.6 & 8.1 & 43.2 & 45.0 \\
\hline & MS & 5.2 & 9.4 & 32.3 & 53.1 \\
\hline \multirow{2}{*}{$\begin{array}{l}\text { Sometimes pupils remain in school even after the } \\
\text { school has closed down when food is in school. }\end{array}$} & $\mathrm{RS}$ & 1.8 & - & 15.3 & 82.9 \\
\hline & MS & 1.0 & - & 11.5 & 87.5 \\
\hline
\end{tabular}

The findings in Table 2 indicated that majority, 60.4 percent, of teachers in regular schools strongly agreed that the regular school provided meals to all pupils on a daily basis. Another 35.1 percent of the teachers also agreed with this statement. Majority of the teachers from mobile schools strongly agreed, 76.0 percent, and agreed, 24.0 percent, that their schools provided meals to all pupils on a daily basis. This percentage was higher than that of regular schools, meaning more mobile schools than regular schools provided meals to their pupils on a daily basis. These figures implied that most of the schools provided meals to pupils on a daily basis.

However, 89.2 percent of teachers from regular schools and 80.2 percent from mobile schools strongly disagreed that the meals provided were dietary and nutritious. This implied that the food provided in all the schools were not dietary and nutritious. Therefore, although all the public primary schools in Turkana County had done well to provide meals daily, the meals were not providing the pupils with the requisite nutrition. The study findings also went against the proposal by Wolpert and Wheeler (2008) who propose that school feeding programmes should be used as opportunities to provide Omega-3 fatty acids to learners to enhance their growth. This finding also contradicted the proposal by Taylor (2009) that because pastoralist communities experience drought frequently, children who are stunted, anaemic experience hunger or have poor dietary intakes tend to have poorer school performance including late enrolment and poor attendance, behaviour, cognation and achievement levels. Therefore, availing the requisite nutritional and related interventions at schooling period will enhance the pupils' achievement.

The results in Table 2 further indicated that most, 89.2 percent, of the regular schools teachers and 88.5 percent from mobile schools strongly agreed that when meals were not provided in regular schools the cases of attendance were reduced. These findings demonstrated that the provision of meals did indeed support participation in schooling. The 
teachers further agreed strongly (94.6 percent from regular and 92.7 percent from mobile schools) that the school solely relied on the government and well-wishers for food donations. These statistics showed that in regular schools, all the schools solely relied on the government and well-wishers for food donations.

The results in Table 2 also showed that, according to most, 45.0 percent and 43.2 percent, of the regular school teachers who strongly agreed and agreed, respectively, sometimes they sent pupils to collect firewood and water. Similarly, 53.1 percent of the mobile school teachers stated that sometimes their schools sent the pupils to collect firewood and water. This statement also had 32.3 percent of the teachers who agreed. These findings revealed that most of the schools sent pupils out of school to collect firewood and water. This action was deemed to take away some time from the teaching and learning activities leading to poor coverage of syllabus, among other negative effects.

Lastly, the findings showed that majority of the teachers from the regular schools, 82.9 percent, strongly agreed that sometimes pupils remained in school even after the school had closed down when food was in school. In the mobile schools, 87.5 percent of the teachers strongly agreed with this statement. Therefore, it was deduced that in almost all schools, sometimes pupils remained in school even after the school had closed down when food was in school.

\subsection{Teachers' Views on Measures to Enhance Effectiveness of School Feeding}

The study further probed the teachers on the measures needed to ensure the school feeding programmes in their schools were effective. Their views were as shown in Table 3.

Table 3. Teachers' views on measures for effective feeding programme

\begin{tabular}{lcccc}
\hline \multirow{2}{*}{ Measures } & \multicolumn{2}{c}{ Regular schools } & \multicolumn{2}{c}{ Mobile schools } \\
\cline { 2 - 5 } & $\mathrm{f}$ & $\%$ & $\mathrm{f}$ & $\%$ \\
\hline Provide balanced diet daily & 33 & 29.7 & 23 & 24.0 \\
$\begin{array}{l}\text { Provide at least two meals } \\
\text { daily }\end{array}$ & 93 & 83.8 & 71 & 74.0 \\
$\begin{array}{l}\text { Introduce free milk/meat to } \\
\text { schools }\end{array}$ & 68 & 61.3 & 53 & 55.2 \\
$\begin{array}{l}\text { Parents should be included in } \\
\text { feeding programmes }\end{array}$ & 66 & 59.5 & 52 & 54.2 \\
Valid n & \multicolumn{2}{c}{111} & & \multicolumn{2}{c}{96} \\
\hline
\end{tabular}

The study results in Table 3 above showed that, according to some teachers, both regular, 29.7 percent, and mobile, 24.0 percent, schools should provide balanced diet daily. This measure was supported by more teachers in regular schools than in mobile schools.

A good number, 83.7 percent, of the teachers from the regular schools also stated that their institutions needed to provide at least two meals daily. This sentiment was also shared by a significant number, 73.9 percent, of teachers from the mobile schools. Therefore, this measure was of great significance in both school categories. This was indicative of the fact 
that, to the teachers, increasing the quantity of food takes priority over the quality (e.g. nutritious value) of the food. Moreover, 61.3 percent of teachers from the regular schools and 55.2 percent mobile schools proposed that their institutions should introduce free milk or meat to schools. Again, this was a suggestion meant to cater to the fact that all the schools reported that the meals provided were not nutritious.

Lastly, many of the teachers suggested that parents should be included in feeding programmes. This view was supported by 59.5 percent of the teachers from regular schools and 54.2 percent of the teachers from the mobile schools. Perhaps the teachers felt that parents understood best the nutritious needs of their children. Therefore, involving parents in school feeding programmes would better guarantee the quality of the meal provided.

From the results above, it was evident that a majority of the teachers were of the opinion that introducing milk and meat as part of school meals would improve the feeding programme in schools. This support the earlier results which indicated that the food provided did not meet the nutritional value recommended. The introduction of milk and meat will bolster the nutritional worth of the food offered. The teachers also were of the opinion that there was need to provide three meals per day, as shown in Table 3. This would ensure that pupils are provided with meals in the morning, midday and in the evening. This would improve the retention rates at schools. The results also show that enough food rations need to be provided to ensure that pupils get satisfied hence increase the concentration rates in class. The teachers also opined that there is need to provide parents with relief food so that pupils can get food at home especially on non-school days. This would ensure that they is continuous provision of food at school and at home.

The findings in Table 4 imply that, according to the teachers, provision of balanced diet is a determining factor of the effectiveness of the school feeding programme as an educational intervention. Another factor that determines the programme's effectiveness, according to the findings, was increasing food quantities to enhance rations given to pupils. Moreover, the effectiveness of the programme was hinted to rely on diversification through provision of such additives as milk or meat. The results also showed that involving parents in planning can enhance the effectiveness of the school feeding programme.

\subsection{Head Teachers' Views on School Feeding}

The head teachers also responded to certain statements related to school feeding programme and pupils' participation in primary education in Turkana County. Their feedback was as presented in Table 4. 
Table 4. Head teachers' views on the feeding programme in mobile schools

\begin{tabular}{|c|c|c|c|c|c|}
\hline \multicolumn{6}{|c|}{ RS-Regular Schools $(n=49)$, MS-Mobile Schools $(n=96)$} \\
\hline & $\begin{array}{l}\text { School } \\
\text { S }\end{array}$ & SD & $\mathrm{D}$ & A & SA \\
\hline \multirow{2}{*}{$\begin{array}{l}\text { This school is a beneficiary of the School Feeding } \\
\text { programme }\end{array}$} & $\mathrm{RS}$ & 0.3 & 0.2 & 35.1 & 60.4 \\
\hline & MS & - & - & 24.0 & 76.0 \\
\hline \multirow[t]{2}{*}{ The meals provided are dietary and nutritious } & $\mathrm{RS}$ & 89.2 & 10.8 & - & - \\
\hline & MS & 80.2 & 19.8 & - & - \\
\hline \multirow{2}{*}{$\begin{array}{l}\text { When meals are provided attendance is high in all } \\
\text { classes }\end{array}$} & $\mathrm{RS}$ & - & - & 10.8 & 89.2 \\
\hline & MS & - & - & 11.5 & 88.5 \\
\hline \multirow{2}{*}{$\begin{array}{l}\text { When meals are not offered we witness reduced cases } \\
\text { of attendance }\end{array}$} & $\mathrm{RS}$ & - & - & 5.4 & 94.6 \\
\hline & MS & - & - & 7.3 & 92.7 \\
\hline \multirow{2}{*}{$\begin{array}{l}\text { The school solely rely on the government and } \\
\text { well-wishers for food donations }\end{array}$} & $\mathrm{RS}$ & 3.6 & 8.1 & 43.2 & 45.0 \\
\hline & MS & 5.2 & 9.4 & 32.3 & 53.1 \\
\hline \multirow{2}{*}{$\begin{array}{l}\text { Sometimes we send pupils to collect firewood and } \\
\text { water }\end{array}$} & $\mathrm{RS}$ & 1.8 & - & 15.3 & 82.9 \\
\hline & MS & 1.0 & - & 11.5 & 87.5 \\
\hline \multirow{2}{*}{$\begin{array}{l}\text { Sometimes pupils remain in school even after the } \\
\text { school has closed down when food is in school. }\end{array}$} & $\mathrm{RS}$ & & & & \\
\hline & MS & & & & \\
\hline
\end{tabular}

Findings in Table 4 showed that majority, 98.0 percent, of the head teachers from regular schools strongly agreed that their respective schools were beneficiaries of the school feeding programme. In the mobile schools, 100.0 percent head teachers strongly agreed with this statement. This finding affirmed that all the schools in Turkana County were beneficiaries of the school feeding programme. These findings were reiterative of those of the teachers from both regular and mobile schools.

The research results in Table 4 also showed that majority, 77.6 percent, of the head teachers from the regular schools strongly disagreed that the meals provided were dietary and nutritious. Similarly, in the mobile schools, 77.3 percent disagreed that the meals provided were dietary and nutritious. Therefore, based on these findings, it was deduced that the food provided in all the regular schools were not nutritious. These findings confirmed the responses received from the teachers in both regular and mobile schools. The poor quality of food provided for school feeding does not augur well with the intentions of school feeding in ASALs, namely to provide health support along with educational programmes.

As shown in Table 4, almost all, 89.8 percent, of the head teachers from the regular schools strongly agreed that their schools solely relied on the government and well-wishers for food donations. All (100.0 percent) of the head teachers from the mobile schools strongly agreed with this statement. This implied that schools in Turkana County relied solely on the government and well-wishers for food donations.

The findings also showed that most, 85.7 percent of head teachers from the regular schools and 77.3 percent from the mobile schools strongly agreed that they had witnessed reduced cases of attendance when meals were not offered. Therefore, from these findings it was interpreted that most schools had witnessed reduced cases of attendance when meals were not 
offered. These results were reiterative of those from the teachers from both the regular and mobile schools. These statistics testify to the fact that school feeding programmes enhance enrolment and participation in schooling. This finding concurred with the studies by WFP (2012) and World Bank (2013) which reported that in most developing countries school feeding programmes have led to increased enrolments in education.

Almost half, 49.0 percent, of the head teachers from the regular schools strongly agreed, while half, 50.0 percent and another 31.8 percent from the mobile schools strongly agreed and agreed, respectively, that sometimes pupils remained in school even after the school had closed down when food was in school. This was indicative of the fact that some of the pupils had been motivated to go to school solely by the provision of regular meals, which they most likely missed at home. As such, this was a good testament of the effectiveness of school feeding in promoting pastoralists' pupils' participation in school.

However, majority of head teachers disagreed that sometimes they sent pupils to collect firewood and water, as shown by 53.1 percent in regular schools and 50.0 percent from the mobile schools. This implied that in most schools in Turkana County, academic processes were not interrupted as during such times pupils had to step out of school to collect these items. A good number, of the head teachers in both categories of schools, however, agreed and strongly agreed with this statement. This was indicative of the inequalities in the supply of fuel and water to these schools which forced some teachers and head teachers to send pupils out to fetch these necessities. It was not also clear if the head teachers ensured the pupils were accompanied by security officers whenever they went to fetch such items. The fact that pupils had to be relied on to fetch these items was indicative of the need to provide interventions for supply of alternative cooking energy and water.

\subsection{Head Teachers' Views on Measures to Enhance Effectiveness of School Feeding}

The head teachers from both the regular and mobile schools were also asked to indicate the measures for effective feeding programmes in schools. Their responses were as shown in the table below.

Table 5. Head teachers' views on measures for effective feeding programme

\begin{tabular}{|c|c|c|c|c|}
\hline \multirow[t]{2}{*}{ Measures } & \multicolumn{2}{|c|}{ Regular school } & \multicolumn{2}{|c|}{ Mobile school } \\
\hline & $f$ & $\%$ & $\mathrm{f}$ & $\%$ \\
\hline Dietary food given in schools & 10 & $20.4 \%$ & 10 & $45.5 \%$ \\
\hline Enough food ratio to pupils & 10 & $20.4 \%$ & 12 & $54.5 \%$ \\
\hline $\begin{array}{l}\text { Introduce milk /meat in } \\
\text { schools }\end{array}$ & 12 & $24.5 \%$ & 15 & $68.2 \%$ \\
\hline Provide three meals daily & 12 & $24.5 \%$ & 12 & $54.5 \%$ \\
\hline $\begin{array}{l}\text { Provide parents with } \\
\text { food/feeding programme }\end{array}$ & 5 & $10.2 \%$ & 5 & $22.7 \%$ \\
\hline Valid n & & & & \\
\hline
\end{tabular}


A significant number, 20.4 percent, of the head teachers from regular schools advocated for the provision of dietary food in schools. Another 45.5 percent principals from mobile schools held the same view as their counterparts from the regular schools. Therefore, it was evident that head teachers were persuaded that provision of dietary meals could enhance the effectiveness of school feeding in promoting participation in schooling.

Moreover, 20.4 percent of the head teachers from regular schools and 54.5 percent from mobile schools stated that there should be enough food ratios for pupils in schools. Evidently, more head teachers from mobile schools than from regular schools were convinced that this strategy was needed. Additionally, 24.5 percent of the head teachers of the regular schools suggested the need to introduce milk and meat in schools and this idea was supported by 68.2 percent of the head teachers of the mobile schools. Again, more head teachers from the mobile schools supported this idea compared to those from the regular schools.

Other proposals made by the principals included: provision of three meals daily as was proposed by 24.5 percent head teachers of regular primary schools and 54.5 percent head teachers of mobile schools and providing parents or guardians with food or feeding programme (regular schools' head teachers $=10.2$ percent and mobile schools' head teachers $=22.7$ percent). According to the principals, these strategies would ensure that the school feeding programmes in their schools will contribute to increased participation in education among parents and learners. The findings seemed to suggest that the mobile schools were in need of more of these measures than did the regular schools, based on the differences in the number of head teachers across the school categories.

These findings showed that head teachers were aware of the need or value of provision of dietary food to pupils. To them, proper nutrition is a measure of the quality or effectiveness of school feeding as an intervention. The head teachers also raised concern on the quantity of food. They urged for sufficient food quantities. The head teachers advocated for sufficient ratios of up to three meals a day to enhance nutrition and pupils' attendance of school.

The research findings were in line with Taylor (2009) who argued that children who are stunted, anaemic experience hunger or have poor dietary intakes tend to have poorer school performance including late enrolment and poor attendance, behaviour, cognation and achievement levels. Thus they are more averse to abandon education early and repeat grades. Availing suitable dietary and well-being interventions at schooling stage will enhance the learners' achievement. Improving well-being and nourishment among youngsters leads to increased registration, school presence, reduced dropout rates, boosted academic output and to social equity and economic growth as healthy persons have the energy to work.

In addition, Kariuki et al. (2013) contended that Makueni District in Kenya had been providing school lunches to every school with a lot of support from the World Food Programme (WFP), parents assist to produce some foodstuffs. The aim was to ensure that children are not hungry. Performance was attributed to a viable SFP. Shortfalls in infrastructure and fiscal materials have complicated the rolling out of lasting SFPs in ECDE institutions across Kenya. Undernourished learners utilise low body strength and other vital 
nutrients while over-fed ones become obese leading to health complications and social anxiety. This will affect the children's academic output in educational centres.

\subsection{Parents' Views on School Feeding and Educational Participation}

In the Focus Group Discussions, all the parents affirmed that schools received food from government. Some parents said they were aware that the World Food Programme supplied maize and beans to schools. However, as some parents pointed out, day schools only provided lunches to the children. All the three Education Officers also said all the public primary schools in their respective sub-counties received food within the school feeding programme. However, as one Officer added not all schools receive the same quantity of foods. He said food was given according to pupil population, location of the school. On his part, the County Director of Education said all the public primary schools did receive food from the government. He added that there had been no reports of schools missing food supply.

The parents further affirmed that the supply of food almost always delayed in the schools. Similarly, all the Education Officers acknowledged that they had received reports of food delays to schools in their respective Sub-Counties. The Education Officers and the Director of Education attributed these delays insecurity, bad roads, bad weather and lack of means of transportation. The above statement showed that the supply of food to schools experienced delays mainly due to poor infrastructure and insecurity issues. This response also hinted to the problem of the effect of insecurity on schooling in the County. It also betrayed the fact that the government had not provided effective interventions to offer sufficient security to educational programmes in the County.

Asked to state if children only went to school whenever there was food provided, the parents responded that the food was provided to learners who were in school and only during school days. Therefore, as one parent explained, the children had not reason to go to school on holidays because schools never provided food during holidays. This was in line with the response from the education Officers, all of whom reported that the provision of meals in schools had enhanced pupils' enrolment as well as pupils' stay in school. These responses affirmed the responses from the County Director of Education, that school feeding programme had enhanced attendance and stay in school by most pupils. According to the CDE, school feeding made pupils to stay longer in school. This finding concurred with that of Pediatre (2001) who found that attendance and school performance were greatly enhanced by school feeding programme.

The researcher also asked the parents to state the measures they would want the government to take on feeding programme in order to ensure the programme best contributed to improving participation of their children in schools. Majority of the parents supported the idea of government providing enough food to cater for breakfast, lunch and supper for learners. Some suggested that orphaned children and children whose parents had migrated far to be provided with food during holidays. Lastly, the parents insisted that the food provided should be dietary and balanced. Subsequently, they urged the government to introduce free primary milk, meat and other supplement to school meals. On the same question of measures, the Education Officers also proposed the need to supply enough and road-worthy vehicles to 
transport food to schools. The above statement revealed that security interventions were the most urgent measures needed to ensure the effectiveness of both school feeding and free primary education, as well as the overall teaching and learning activities in the schools.

In the interviews, the three Education Officers were asked to describe the government policy on school feeding programme as it applied to Turkana County. One Officer explained that they were required by the Directorate to conduct regular evaluation of the status of school feeding programme implementation in their respective sub-counties and give reports to the Directorate for further action. This indicated that there was a proper policy structure for implementing the school feeding programme in the three sub-counties across the entire county. This finding concurred with the view by Jensen (2010) that school feeding mostly takes place within the context of broad national school reform programs. These reforms should focus on other essential inputs to education and learning such as teacher development, curriculum reforms and student assessment. According to the County Director of Education, the Kenya government came up with the idea of providing school meals as part of its attempt to realize the Millennium Development Goals of reducing hunger and ensuring access to universal free primary education. The Director reported that the programme catered to only day time meals, which comprised mid-morning snacks and drinks, lunch and evening snacks and drinks. He said parents were also encouraged to supply meals to schools when they could. Therefore, he explained further, the policy had been cascaded down to Turkana County through the Directorate of Education.

\subsection{Hypothesis Test Results}

The study hypothesised that the government's school feeding programme does not significantly affect pastoralists' pupils' participation in the regular and mobile primary schools in Turkana County. To test the hypothesis, a simple linear regression between school feeding programme and pupils participation in schools was carried out. The resultant model summary and coefficient tables summarised the results.

Table 6. Regression model on effectiveness of school feeding

\begin{tabular}{lcccc}
\hline Model & $\mathrm{R}$ & $\mathrm{R}$ Square & $\begin{array}{c}\text { Adjusted R } \\
\text { Square }\end{array}$ & \begin{tabular}{c} 
Std. Error of the Estimate \\
\hline 1
\end{tabular} \\
\hline $8443^{\mathrm{a}}$ & .713 & .718 & .2240 \\
a. Predictors: (Constant), School Feeding Programme & \\
\hline
\end{tabular}

Table 6 is the first regression output that indicates whether the model is fit to draw conclusion about regression results. It has the R, R Squared and Adjusted R Squared. In this case the R indicates the correlation result that is whether there is correlation of the variables of interest. For this study $R$ value represent the simple correlation (0.8443), which indicated a high degree of correlation. The $R^{2}$ value (the "R Square" column) indicated how much of the total variation in the dependent variable, participation of pastoralists pupils in regular and mobile primary school, can be explained by the independent variable, school feeding programme. In this case, $71 \%$ of variance in pupil participation in schooling is explained by the school 
feeding programme. The table also indicates that adjusted $r$ Squired (.718) indicating that the model has a higher predictive power.

The regression model indicate that the coefficient of determination is 0.71 ; therefore, about 71 percent of the school participation was explained by school feeding programme. This implied that school feeding programme as one of the government interventions was an important predictor of pupils' participation in both regular and mobile schools in Turkana County.

Table 7. Relationship between School Feeding Programme and Pupils' Participation

\begin{tabular}{|c|c|c|c|c|c|}
\hline \multirow[t]{2}{*}{ Model } & \multicolumn{2}{|c|}{$\begin{array}{c}\text { Unstandardized } \\
\text { Coefficients }\end{array}$} & \multirow{2}{*}{$\begin{array}{c}\text { Standardized } \\
\text { Coefficients }\end{array}$} & \multirow[t]{2}{*}{$\mathrm{T}$} & \multirow[t]{2}{*}{ Sig. } \\
\hline & $\mathrm{B}$ & Std. Error & & & \\
\hline \multirow{3}{*}{$\begin{array}{ll}1 & \text { (Constant) } \\
& \text { School feeding } \\
\text { a. Dependent Variab }\end{array}$} & 3.23 & .212 & & 11.119 & .000 \\
\hline & -.767 & .111 & -.724 & -7.298 & .000 \\
\hline & \multicolumn{5}{|c|}{ a. Dependent Variable: school participation } \\
\hline
\end{tabular}

The results in Table 7 indicated that the unstandardized coefficients of (-.767) and the standardized coefficients of (-.724) had a significance of (.000). It indicated that there is a statistically significant relationship between school feeding programmes and pupils participation in schools as indicated by $(p$ value $<0.05)$. This therefore leads to a rejection of the null hypothesis that school feeding programme does not significantly affect pastoralists' pupils' participation in the regular and mobile primary learning institutions in the County of Turkana.

\section{Conclusion and Recommendations}

Regarding the issues of school feeding programme, it is concluded that meals are provided in both regular and mobile public primary schools in Turkana County. The government has a well-defined policy for implementing the school feeding programme. Education Officers are mandated to report issues regarding food supply to schools to the Directorate for further action. The food provided by the government is not nutritious. The provision of meals in school has enhanced attendance and stay in school by pupils. Majority of the schools rely solely on the government and well-wishers to provide food for the pupils. The World Food Programme supplies mainly maize and beans to schools. However, most schools encourage parents to supply meals to schools when they can. Due to lack of fuel and reliable source of water for preparing school meals, sometimes many of the schools send pupils to collect firewood and water, which disrupts teaching and learning activities. The supply of food to schools often experiences delays due to bad roads, poor quality and few transport vehicles and insecurity. Overall, school feeding programme has a significant effect on pastoralists' pupils' participation in the regular and mobile primary schools in Turkana County.

To improve the effectiveness of school feeding programme as an intervention, it was recommended that there is a need to increase the quantities of food provided to enable schools to provide at least three meals per day to pupils. There is also a need to strengthen and diversify the nutritive value of the meals provided to pupils. One of the measures 
proposed in the study was the introduction of milk or meat into meals. Moreover, there is a need to engage or involve parents when planning and providing of school meals. Additionally, some of the orphaned children and children whose parents have migrated far should be provided with food during holidays. The national and county governments should also strive to eradicate delays of food supplies to schools. Moreover, the government should provide security to vehicles that transport food to schools. Lastly, there is also a need to provide more roadworthy vehicles to supply food to schools.

\section{References}

Abdirahman, F. A. (2016). Somali pastoralism in transition from traditional to modern methods of livestock keeping: A case study of Somali pastoralists in Wajir County (MA Thesis). Univeristy of Nairobi.

Adan, L. (2010). The transitions Impediments among the girls in Learning Institutions in Tanzania. UNITA Conference Report. Tanzania.

Adelman, S. W., Gilligan, D. O., Lehrer, K. (2008). How effective are food for education programs? A critical assessment of the evidence from developing countries. International Food Policy Research Institute. https://doi.org/10.2499/0896295095FPREV9

Aderinoye, R., K. Ojokheta, K., \& Olojede, A. (2007). Integrating mobile learning into nomadic education programmes in Nigeria: Issues and perspectives. International Review of Research in Open and Distance Learning, 8(2). https://doi.org/10.19173/irrodl.v8i2.347

Bundy, D., Burbano, C., Grosh, M., Gelli, A., Jukes, A., \& Drake, L. (2009). Rethinking School Feeding: Social Safety Nets, Child Development, and the Education Sector. World Bank. https://doi.org/10.1596/978-0-8213-7974-5

Carr-Hill, R., Eshete, A., Sedel, C., \& de Souza, A. (2005). The Education of Nomadic Peoples in East Africa Synthesis Report. Paris: UNESCO.

Greenhalgh, T., Kristjansson, E., \& Robinson, V. (2007). Realist review to understand the efficacy of school feeding programmes. BMJ, 27(7625), 858-61. https://doi.org/10.1136/bmj.39359.525174.AD

Mugisha, I. R. (2012, August 16). Rwanda; New School Feeding Programme in the Pipeline. The New Times. The New Times Newspaper.

Hutchinson, M., Vickers, M., Jackson, D., \& Wilkes, L. (2006). "Like Wolves in a Pack": Stories of Predatory Alliances of Bullies in Nursing. Retrieved June 20, 2019 from https://www.anzam.org/wp-content/uploads/pdf-manager/2416_HUTCHINSON_MARIE_O B-16.PDF

Jensen, B. (2000). Dr. Jensen's Nutrition handbook: A Daily Regimen for Healthy Living (1 ${ }^{\text {st }}$ ed.). McGraw-Hill Education. 


\section{Al Macrothink}

Journal of Studies in Education

ISSN 2162-6952 2020, Vol. 10, No. 4

Kariuki, B. M., Chepkoech, B., Muthoni, B., \& Kosgei, L. (2013). Emerging Trends in Educational Research and Policy Studies. Journal of Emerging Trends in Educational Research and Policy Studies, 4(3), 45-54.

Kratli, S. (2001). Educating Nomadic Herders out of Poverty? Culture, Education, and Pastoral Livelihood in Turkana and Karimoja. University of Sussex, Institute of Development Studies.

Migosi, J., Nanok, D., Ombuki, C., \& Metet, J. (2012). Trends in Primary school dropout and completion rates in the pastoralist Turkana County, Kenya. Universal Journal of Education and General Studies, 1(10), 331-338.

Mutangadura, G., Mukurazita, D., \& Jackson, H. (2003). A review of household and community responses to the HIV/AIDS epidemic in the rural Sub-Saharan Africa. Geneva, Switzerland: Joint United Nations Program on HIV/AIDS (UNAIDS).

NEPAD (2005a). CAADP Summary for the Southern Africa Regional Implementation Planning meeting. NEPAD.

NEPAD (2005b). NEPAD School Feeding Programme; Annual Operating Plan. NEPAD.

Nkinyangi, J. (1981). Education for pastoralists: Development planning by trial and error. In D. A. J. G. Galaty (Ed.), The Future of Pastoralists People. Ottawa: International Research Centre.

Pediatre, J. (2001). Effects of Children Nutrition. Paris: Longhorn Publishers.

Porta, E., \& Wils, A. (2013). Review and Evaluation of Selected Education Projection Models in use in 2006. Retrieved June 23, 2019 from https://www.researchgate.net/publication/265751204_Review_and_Evaluation_of_Selected_ Education_Projection_Models_in_use_in_2006/download

Powell, M. C., \& Fazio, R. H. (2006). Attitude Accessibility as a Function of Repeated Attitudinal Expression. Personality \& Social Psychology Bulletin, 10(1), 139-148. https://doi.org/10.1177/0146167284101016

Sifuna, D. (2005). Increasing Access and Participation of Pastoralist Communities in Primary Education in Kenya. International Review of Education, 51, 499-516. https://doi.org/10.1007/s11159-005-8260-9

Taylor, A. K. (2009). School Feeding Programme in Kenya Nairobi: East African

Tilak, J. B. G. (2005). Global Trends in the funding of Higher Education. IAU Horizons, 11(1), 1-3.

UNICEF (2007). Nomadic Education in the Islamic Republic of Iran. Eastern and Southern Africa Regional Office (ESARO).

UN Hunger Task Force (2004). Halving Hunger: It Can Be Done. UN Hunger Task Force, New York. 


\section{Macrothink}

Journal of Studies in Education

ISSN 2162-6952 2020, Vol. 10, No. 4

United Nations (2005a). UN Millennium Project. Halving Hunger: It can be done; Summary version of the report of the Task Force on Hunger. UN.

United Nations (2005b). United Nations Millennium Development Goals, Vol. 2007. UN.

World Bank (2013). Global monitoring report 2013: rural-urban dynamics and the millennium development goals (English). Washington D.C.: The World Bank.

World Food Programme (2006a). Food for Education, experts seminar: Reviewing the evidence. WFP.

World Food Programme (2006b). World Hunger Ghana, Vol. 2006. WFP.

World Food Programme (2007). World Hunger Series: Hunger and Health. WFP.

World Food Programme (2007). Cameroon: School Meals 'Graduate’ Says Thanks. WFP.

World Food Programme (2012). Rwanda to Implement School Feeding Programme after visit to Brazil. Retrieved June 20, 2019 from https://www.wfp.org/blog/blog/rwanda-implement-school-feeding-programme-after-study-vi sit-brazil

Wolpert, S., \& Wheeler, M. (2008). Food as brain medicine. UCLA Magazine Online. Retrieved http://magazine.ucla.edu 